Justyna Dobrołowicz*

Kielce

\title{
Mediatyzacja współczesności a procesy socjalizacji i wychowania
}

Celem artykułu jest analiza procesów socjalizacji i wychowania przebiegających we współczesnej rzeczywistości, w której środki masowego przekazu zdominowały życie niemalże każdego człowieka. Codzienne obserwacje pozwalają stwierdzić, że wielu odbiorców mediów buduje swoje wyobrażenia o świecie, opierając się na tym, czego dowiaduje się ze środków masowego przekazu i to wpływa na ich sposób rozumienia siebie, świata i swojego miejsca w świecie. Teorie i wyniki badań nad efektami komunikowania masowego ${ }^{1}$ pokazują że próby określenia siły mediów i ustalenia skutków ich oddziaływania nie prowadzą do jednoznacznych wniosków. Ciaggle nie wiadomo, czy oglądanie przez dzieci scen przemocy w programie telewizyjnym nasila zachowania agresywne, czy obecność pornografii w mediach prowadzi do patologicznych zachowań społecznych w tym zakresie. Na te pytania można odpowiedzieć: „czasem tak, czasem nie”. Od czego jednak

* Dr hab. Justyna Dobrołowicz pracuje w Zakładzie Pedagogiki Ogólnej i Metodologii Badań Uniwersytetu Jana Kochanowskiego w Kielcach.

${ }^{1}$ Por. M. Filipiak, Homo communicans, wprowadzenie do teorii masowego komunikowania, Lublin 2003; T. Goban-Klas, Media i komunikowanie masowe. Teorie i analizy prasy, radia, telewizji i Internetu, Warszawa-Kraków 2001; D. McQuail, Teoria komunikowania masowego, Warszawa 2007; M. Mrozowski, Media masowe: władza, rozrywka, biznes, Warszawa 2001; B. Dobek-Ostrowska (red.), Nauka o komunikowaniu. Podstawowe orientacje teoretyczne, Wrocław 2001. 
zależy to, kiedy „tak”, a kiedy „nie” - dokładnie nie wiadomo. Równolegle z krytycznymi ocenami mediów pojawiały się - i ciagle się pojawiają - głosy, że media odgrywają też pozytywną rolę jako potężny czynnik masowej edukacji, zwłaszcza ważnej dziś edukacji permanentnej; że to właśnie dzięki mediom dokonuje się rozwój demokracji i postęp naukowo-techniczny; że poprzez media można popularyzować wartościowe społecznie zasady, poglądy i wzory zachowania.

Rola, jaką w społeczeństwie odgrywają media, nie jest więc jednoznaczna i ciaggle budzi szereg wątpliwości. Niezależnie jednak od tych rozbieżnych opinii jedno jest pewne: skoro media kreują dziś rzeczywistość społeczna, ustalają modele, normy i standardy zachowania, nie wolno pozostawiać ich poza obszarem zainteresowań pedagogiki.

\section{Socjalizacja i wychowanie w kulturze prefiguratywnej}

W tradycyjnym świecie socjalizacja była procesem transmisji i dziedziczenia stabilnej hierarchii wartości, dzięki czemu jednostka stawała się pełnowartościowym członkiem społeczeństwa. Pojęcie „,socjalizacja”2 można rozumieć $\mathrm{w}$ szerszym lub węższym znaczeniu. W znaczeniu węższym odnosi się ono do wczesnych faz rozwoju jednostki, kiedy małe dziecko jest wprowadzane do udziału w życiu społecznym i przyswaja sobie akceptowane sposoby zachowania. W szerszym znaczeniu socjalizacja pojmowana jest jako całokształt procesów wzajemnego oddziaływania jednostki i jej środowiska społeczno-kulturowego. Tak rozumiana socjalizacja trwa przez całe życie i obejmuje zarówno przyswajanie wymogów środowiska oraz przystosowywanie się do niego, jak też przekształcanie środowiska w wyniku własnych działań. W skład szeroko rozumianej socjalizacji wchodzą zarówno procesy inkulturacji, jak i wychowania, czyli intencjonalnych działań pedagogicznych, zmierzających do osiagnięcia względnie stałych skutków w osobowości wychowanka ${ }^{3}$. Dzięki socjalizacji jednostka uczy się społecznie akceptowanych sposobów ukierunkowywania swoich popędów

2 A. Jasińska-Kania, Socjologiczna koncepcja osobowości, w: Z. Krawczyk, W. Morawski (red.), Socjologia. Problemy podstawowe, Warszawa 1991, s. 78-99.

${ }^{3}$ W literaturze pedagogicznej istnieje szereg koncepcji wychowania. Na potrzeby artykułu przyjęłam tradycyjne rozumienie tego pojęcia. O trudnościach w nadaniu znaczenia kategorii „wychowanie” pisze wielu autorów. Zob. B. Śliwerski, Pedagogika ogólna: podstawowe prawidłowości, Kraków 2012. 
i zaspokajania potrzeb; nabywa umiejętności posługiwania się przedmiotami oraz sprawności techniczne niezbędne do życia w cywilizacji; opanowuje umiejętności komunikacyjne; kształtuje sposoby odczuwania i wyrażania emocji i w końcu, dzięki socjalizacji następuje uwewnętrznienie upowszechnionych w społeczeństwie wartości, aspiracji, celów działania, norm, wzorów osobowych.

Do niedawna główną agendą socjalizacji była rodzina, to właśnie tutaj jednostka kształtowała swój system wartości, nabywała umiejętności społeczne, które pozwalały jej zintegrować się ze społeczeństwem, uczyła się odgrywania rozmaitych ról społecznych. Dzięki rodzinie młody człowiek bardzo wcześnie dowiadywał się, jaki ma być, jak powinien postępować i czego mu robić nie wolno. Każda jednostka już od wczesnego dzieciństwa formowana była w taki sposób, by dobrze funkcjonować w środowisku społecznym, w którym żyła. Efektem zabiegów socjalizacyjnych był człowiek jasno zdefiniowany i jednoznaczny. Cechy jego tożsamości były funkcjonalne w świecie, w którym żył, przez co stosunkowo łatwo odnajdywał się w społeczeństwie.

Taki sposób socjalizowania dzieci był funkcjonalny w dwóch poprzednich stadiach rozwoju kultury: kulturze określanej przez socjologów jako postfiguratywna i kofiguratywna ${ }^{4}$.

Kultura postfiguratywna, której podstawą rozwoju i trwania była niezmienność wartości, rozwijała się od okresu prehistorycznego aż do połowy XVIII wieku. Najbardziej charakterystyczną jej cechą jest niezmienność norm i zasad życia społecznego. Dzięki tej stabilności świat społeczny jawił się jako jasny, uporządkowany i przewidywalny. Starsze pokolenie, jako bardziej doświadczone, przekazywało młodym zasób wiedzy, umiejętności, poglądów i wartości, który zapewniał im prawidłowe przystosowanie do rzeczywistości społecznej. W tym stadium rozwoju kultury tradycyjna rodzinna socjalizacja, oparta na przekazie międzypokoleniowym, postrzegana była nie tylko jako działanie pozytywne, ale nawet jako niezbędne. Kwestionowanie autorytetów pojawiało się rzadko i nie miało dużego znaczenia. Zarówno starzy, jak i młodzi ludzie cenili międzypokoleniową transmisję wartości, która zapewniała młodemu pokoleniu przystosowanie do życia społecznego.

Kultura kofiguratywna natomiast to czas od rewolucji przemysłowej do końca drugiej wojny światowej, w którym następowały przemiany zarówno gospodarcze, jak i społeczne. Świat podlegał dynamicznym zmianom i coraz

${ }^{4}$ M. Mead, Kultura i tożsamość. Studium dystansu międzypokoleniowego, Warszawa 2000. 
częściej doświadczenia dorosłych członków społeczeństwa były odmienne od doświadczeń ludzi młodych. Koniecznością stała się wymiana poglądów, doświadczeń i sposobów widzenia świata między pokoleniami.

Międzypokoleniowa transmisja wartości nabiera charakteru dwukierunkowego. Starsi członkowie społeczeństwa w obliczu rozprzestrzeniających się zmian nie mają już monopolu na prawdę i wiedzę o zmieniającym się świecie. Ich doświadczenia nadal są podstawą socjalizacji młodszego pokolenia, ale ci sami młodzi u progu dorosłości stają się na równi z rodzicami i dziadkami kompetentni społecznie, wyposażeni w doświadczenia i rodzaje wiedzy, których starszym ludziom brak. Konieczna jest zatem wymiana poglądów, perspektyw i sposobów widzenia rzeczywistości, świat bowiem przestaje być oczywisty i przewidywalny5.

I wreszcie ostatnie, aktualne, stadium rozwoju: charakterystyczna dla naszych czasów - kultura prefiguratywna. Jest to kultura, w której doświadczenia młodego pokolenia nie mają odpowiednika w doświadczeniu rodziców i dziadków. Przodkowie nie dostarczają młodzieży żadnych praktycznych wzorów zachowania, ponieważ cywilizacja, w której żyją, jest dla nich zupełnie nowa. Przekaz międzypokoleniowy, powszechny w tradycji i bardzo potrzebny, w tej kulturze przestaje odgrywać ważną rolę. Podstawowe zagrożenia socjalizacji młodego pokolenia we współczesnej kulturze prefiguratywnej dotyczą niepewności zachowania i rozchwiania systemu wartości. Zagrożenia te potęguje fakt, że dziś nikt nie wie, co przyniesie przyszłość, na co się przygotować, czego nauczyć. Współczesny niestabilny i zróżnicowany świat nie oferuje człowiekowi jednoznacznych podpowiedzi, drogowskazów prowadzących przez życie; zmusza do ciagłego wybierania, decydowania, eksperymentowania i kwestionowania. Jak nigdy dotąd jednostka otrzymuje bogaty wachlarz możliwości tworzenia siebie i budowania własnej tożsamości. Sytuacja ta jest niewątpliwie bardzo atrakcyjna, ale jednocześnie bardzo trudna. Gdy świat społeczny stwarza szereg możliwości, człowiek traci orientację w tym, co jest dobre, a co złe, co powinien wybrać, a co odrzucić. Rygorystyczne wychowanie tradycyjne zastapione zostało permisywizmem, a w konsekwencji coraz częściej pajdokracją. Bezpośrednim następstwem tego stanu rzeczy jest zagubienie moralne młodego pokolenia, przejawiające się relatywizacją wartości i negowaniem dotychczasowych autorytetów. Większa wolność jednostki to jednocześnie więk-

${ }^{5}$ M. Karkowska, T. Skalski, Kultura, socjalizacja, tożsamość, Kraków 2010, s. 16. 
sza odpowiedzialność za kształt swojej tożsamości, za swoje życie. Wolność nieoparta na mocnych fundamentach, którymi są przyswojone uniwersalne wartości podstawowe, może prowadzić do frustracji, braku poczucia bezpieczeństwa, wyobcowania i anomii. Najnowsze koncepcje wychowania za najważniejsze uznają ukształtowanie w wychowankach niezależności i krytycyzmu wobec zastanych norm moralnych i zakładają, że młodzi ludzie sami, bez żadnych wskazówek, będą umieli odróżnić to, co dobre i pożyteczne, od tego, co szkodliwe i złe. K. Maliszewski zauważa, że w piśmiennictwie pedagogicznym spotykamy dziś coraz częściej sądy o charakterze antyhierarchicznym, to jest stwierdzenia, „które odmawiają wartości autorytetom, wzorcom, kanonom, kwestionują zasadność formułowania i przekazywania ocen z roszczeniem powszechnej ważności, czyli zaprzeczają implicite (lub czasem explicite) istnieniu obligującej hierarchii w wyborze dóbr, w tym postaw życiowych i wiedzy"6. Podsumowując, socjalizacja i wychowanie w kulturze prefiguratywnej to coraz częściej swobodny proces różnorodnych oddziaływań, nieoparty na godnych przekazania wartościach i autorytetach.

\section{Mediatyzacja współczesności}

Współcześni rodzice większość czasu spędzają poza domem, zajęci zawodową praca, życiem towarzyskim i własnym rozwojem. A ich dzieciom wolny czas po zajęciach szkolnych wypełnia telewizor i komputer. Media to dziś najtańszy i najbardziej dostępny sposób spędzania wolnego czasu. Dlatego nawet jeśli rodzice są $\mathrm{w}$ domu, również wtedy zamiast rozmowy z dzieckiem coraz częściej wybierają program telewizyjny czy rozmaite, dostępne w Internecie rozrywki. W tej sytuacji coraz częściej młodzi ludzie szukają wskazówek ,jak żyć” właśnie w mediach. Znaleźć tam bowiem można całościowe modele tożsamości wraz z dokładnymi instrukcjami, w jaki sposób można je urzeczywistnić. Są to z reguły modele znacznie atrakcyjniejsze i łatwiejsze w realizacji, a przy tym zazwyczaj znacznie ciekawiej podane od tych, które proponuje rodzina, szkoła czy Kościół.

Oddziaływanie mediów: lansowanie przez nie określonych wzorów zachowań i „nowoczesnego” systemu wartości stało się jedną z przyczyn zupełnie nowej jakości życia społecznego. Dziś media nie są już wyłącznie

${ }^{6}$ K. Maliszewski, Sad antyhierarchiczny w pedagogice, w: J. Dobrołowicz (red.), Zeszyty Naukowe Forum Młodych Pedagogów przy Komitecie Nauk Pedagogicznych PAN, Kielce 2002, s. 57. 
nośnikiem informacji, dostarczają również rytuałów i symboli niezbędnych do kształtowania tożsamości, są źródłem wartości i wzorów postępowania. Dla ludzi prawdą jest nie to, co widzą w pracy czy na ulicy, ale to, co wynika z ostatniego kontaktu z mediami. Dla współczesnego człowieka rzeczywistość jest tożsama z przekazem medialnym i w związku z tym reaguje on na medialne przekazy tak, jakby były one naturalną, obiektywną rzeczywistością. Nasycenie otoczenia człowieka medialnymi przekazami prowadzi do ukształtowania społeczeństwa spektaklu, które wiele lat temu scharakteryzował G. Debord ${ }^{7}$. We współczesnym społeczeństwie to właśnie „elektroniczne techniki komunikacyjne określają, czym jest rzeczywistość, w jaki sposób należy w niej działać, jak oceniać zjawiska w niej występujące, w co wierzyć i komu ufać, jak głosować i przeciwko komu protestować, w co inwestować i co kupować, kto jest winny, a kto nie itd." ${ }^{8}$. Każde zjawisko czy wydarzenie najpierw istnieje w mediach. Tylko bowiem to, co pokazują media, uznawane jest za społecznie istotne. Media, dostarczając wzorców do naśladowania, niejednokrotnie zakłócają procesy socjalizacji i wychowania. Do niedawna dziecko uczone było odróżniania dobra od zła. Dziś ta umiejętność, podobnie jak krytyczne myślenie, nie jest mu do niczego potrzebna. Media dostarczają gotowe „scenariusze zachowań”, dzięki którym młody człowiek nie ma żadnych wątpliwości, jak powinien postapić. Dokonało się i ciągle dokonuje, używając określenia Z. Kwiecińskiego ${ }^{9}$, przesunięcie socjalizacyjne. $\mathrm{W}$ procesach spontanicznego wrastania jednostki w normy i wartości społeczne nastapiło zasadnicze przesunięcie źródeł wpływów i czynników oddziaływania. Rodzina, szkoła i Kościół tracą na zakresie i sile swych wpływów - głównie na rzecz grupy rówieśniczej, mediów i kultury popularnej. „To nie nauczyciel od matematyki i Pani od polskiego, lecz supergwiazdy filmu i estrady kształtują wzory osobowe; to nie treść Lalki Bolesława Prusa czy Trenów Jana Kochanowskiego dyskutowana jest na dużej przerwie, lecz artykuły drukowane w „Cosmopolitan” i strategie przetrwania zawarte w ostatniej przebojowej grze komputerowej" ${ }^{10}$.

${ }^{7}$ G. Debord, Społeczeństwo spektaklu. Rozważania o społeczeństwie spektaklu, Warszawa 2006.

${ }^{8}$ M. Krajewski, Kultury kultury popularnej, Poznań 2005, s. 93.

9 Z. Kwieciński, Tropy - ślady - próby. Studia i szkice z pedagogii pogranicza, Poznań-Olsztyn 2000, s. 90.

${ }^{10}$ Z. Melosik, Kultura popularna jako czynnik socjalizacji, w: Z. Kwieciński, B. Śliwerski (red.), Pedagogika, t. 2, Warszawa 2004, s. 68. 
Rola, jaką w społeczeństwie pełnią media, nie jest jednoznaczna i nadal budzi wiele wątpliwości. Tradycyjnie uznawano, że odbiorcy mediów podlegają silnemu wpływowi nadawców, którzy kontrolują dyskurs medialny i świadomie lub nieświadomie narzucają odbiorcom własne przekonania, poglądy, opinie. A. Grzymała-Kazłowska ${ }^{11}$, powołując się na poglądy J. Baudrillarda, zauważa, że możliwy jest zupełnie inny rodzaj wpływu. To nie masy są manipulowane przez producentów medialnych przekazów, tylko właśnie producenci ulegają ogromnemu wpływowi odbiorców. Muszą dostosować się do oczekiwań publiczności i zaspokajać jej potrzeby. Czy w takim razie można w ogóle mówić o kształtowaniu rzeczywistości przez media, czy raczej o odbiciu w mediach wszystkich problemów trapiących społeczeństwo? Ciagle poszukiwana jest odpowiedź na pytanie o to: czy media wytwarzają rzeczywistość, czy tylko ją reprezentują?

Upowszechnienie środków masowej komunikacji prowadzi do zjawiska określonego terminem mediatyzacja rzeczywistości społecznej, który oznacza „proces pośrednictwa mediów w poznawaniu świata; wpływanie przez media na postrzeganie przez człowieka rzeczywistości niedostępnej bezpośredniemu doświadczeniu wraz z konsekwencjami takiego pośrednictwa; kształtowaniem obrazu całej rzeczywistości społecznej, a nawet kompleksowych doświadczeń społecznych pod wpływem konstrukcji medialnych"12.

Mediatyzacja nie jest zjawiskiem gwałtownym, lecz procesem długotrwałym, ogarniającym jednostki, grupy, instytucje i systemy społeczne i obejmującym wszystkie dziedziny życia: edukację, politykę, pracę, odpoczynek, rodzinę, religię... W wyniku mediatyzacji pojawia się tendencja do internalizacji postaw, wzorów i norm zaczerpniętych bezpośrednio z mediów.

Istotę mediatyzacji rzeczywistości społecznej można sprowadzić do następujących zjawisk:

- ludzie mają szeroki dostęp do medialnych przekazów i są zainteresowani ich odbiorem;

- komunikacja społeczna, w tym komunikowanie masowe, jest istotnym źródłem wiedzy i generatorem wzorów definiowania przez ludzi sensowności życia społecznego;

- ewolucja treści i wzorów komunikowania się może być przyczyną zmiany wzorów zachowań i działań społecznych;

11 A. Grzymała-Kazłowska, Konstruowanie ,,innego”. Wizerunki imigrantów w Polsce, Warszawa 2007, s. 22.

12 W. Pisarek (red.), Stownik terminologii medialnej, Kraków 2006, s. 118. 
- ewolucja mediów podlega prawu Riepla ${ }^{13}$, w wyniku czego ogólnospołeczny zasób możliwości ich oddziaływania stale rośnie;

- media masowe przestały być neutralnym pośrednikiem (mediatorem) między „dysponentem wiedzy” a „odbiorcą przekazu”; dawniejszy prosty kontakt „nadawca-odbiorca” został zastapiony przez sieć powiązań wielu instytucji społecznych i wielu grup odbiorców;

- ewolucja współczesnych mediów podlega prawidłom dotyczącym innych cywilizacyjnych (mega-)procesów: globalizacji, indywidualizacji, komercjalizacji;

- media masowe odgrywają autonomiczną rolę w systemie społecznym i politycznym - to one dostarczają narzędzi działania (komunikacji) innym instytucjom, jak również proponują własną wizję społecznej racjonalności ${ }^{14}$.

Znaczenie procesu mediatyzacji dla kształtowania tożsamości jednostki wyjaśnia J. H. Kołodziej, przywołując poglądy N. Couldry'ego, który wprowadził pojęcie medialnego habitusu ${ }^{15}$. Habitus jest systemem dyspozycji, postaw, schematów myślowych, tendencji działania, reakcji emocjonalnych, nawyków. Choć każdy człowiek może uznawać tę sferę za własną, wyrażającą jego indywidualność i podlegającą jego świadomej kontroli, w istocie habitus rodzi się pod wpływem czynników zewnętrznych, tkwiących głównie w środowisku rodzinnym, szkolnym i klasy społecznej. Można więc habitus określić jako społecznie wpojoną „naturalność”, sferę oczywistości budowaną na gruncie uzgadniania przeżyć subiektywnych jednostki ze społecznie konstruowaną sferą obiektywności ${ }^{16}$. N. Couldry, dostosowując antropologię P. Bourdieu do realiów zmediatyzowanego społeczeństwa XXI wieku, zauważa, że dzięki reprezentowaniu rzeczywistości i nadawaniu znaczeń media stały się dziś podstawowym czynnikiem kształtowania habitusu jednostki.

13 Wolfgang Riepl w 1913 roku sformułował tezę, że kolejne pojawiające się media nie wyprą swych poprzedników, lecz kumulatywnie wzbogacą ich możliwości o nowe funkcje.

14 J. H. Kołodziej, Wartości polityczne. Rozpoznanie, rozumienie, komunikowanie, Kraków 2011, s. 201-202.

15 Tamże, s. 206.

16 T. Szkudlarek, Pozór i zmiana: o epistemologicznych unikach pedagogiki - dekadę i trochę później, „Ars Educandi” 4 (2004), s. 89. 
Upowszechnienie i popularność mediów we współczesnym świecie wynika stąd, że odpowiadają one na różne potrzeby odbiorców i pełnią szereg ważnych funkcji. Większość teoretyków mediów wymienia pięć funkcji pełnionych przez współczesne media.

1. Funkcja informacyjna, polegająca na dostarczaniu informacji o wydarzeniach i sytuacji w kraju i na świecie; na zaspokajaniu ciekawości.

2. Funkcja rozrywkowa, której istotą jest dostarczanie przyjemności, umożliwienie emocjonalnego odprężenia lub pobudzenia; ta funkcja mediów jest szczególnie ważna dla ludzi samotnych, media łagodzą bowiem poczucie osamotnienia, zwiększają poczucie bezpieczeństwa, pomagają organizować porządek dnia.

3. Funkcja mobilizacyjna: zwraca uwagę na fakt, że media mają ogromne możliwości prowadzenia kampanii publicznych w sprawach odnoszących się do sfery polityki, wojny, ekonomii, religii itd.

4. Funkcja korelacyjna mediów wynika $\mathrm{z}$ tego, że mogą one podejmować działania, których celem jest formowanie ładu społecznego. Funkcja ta realizowana jest poprzez wyjaśnianie, interpretowanie i komentowanie znaczenia przedstawianych informacji; zapewnianie wsparcia uznanym autorytetom i normom; socjalizację; koordynację odrębnych działań; budowanie konsensusu w różnych sferach życia zbiorowego; ustalanie hierarchii ważności przedstawianych problemów.

5. Funkcja kontynuacyjna, polegająca na tym, że media wyrażają dominującą kulturę a także wytwarzają i utrzymują wspólnotę wartości. Dzieje się tak, gdyż media umacniają określoną wizję i strukturę rzeczywistości oraz zabezpieczają jej rozwój i trwanie. Przekazy medialne pobudzają do rozmów, do formułowania ocen i opinii, potwierdzają także obowiązujące normy społeczne. Zwykle piętnowanie czy ośmieszanie w mediach pewnych zachowań sprawia, że również w skali społecznej nie są one uznawane. Natomiast uznanie danej normy przez media za właściwą prowadzi do jej społecznej akceptacji.

Badacze mediów twierdzą, że udział mediów w procesach socjalizacji jest oczywisty, chociaż trudny do udowodnienia. Podstawą tego przekonania jest założenie, że: ,media mogą uczyć norm i wartości przez symboliczne nagrody i kary za różne prezentowane zachowania. [...] media uczą jak zachowywać się w określonych sytuacjach i jakie oczekiwania odpowiadają danym rolom i statusom społecznym. Media oferują zatem modele życia 
i wzory zachowań, zanim napotkamy analogiczne sytuacje w prawdziwym życiu"17.

Doskonałym przykładem takiego oddziaływania mediów jest historia opowiedziana przez siedemnastoletnią Jolę, uczestniczkę badań na temat prostytucji nieletnich ${ }^{18}$. Dziewczyna opowiada, że seks zaczęła uprawiać w wieku 15 lat, ponieważ sama tego chciała. Nikt jej nie namawiał, „no chyba że brać „Popcorn” i „Brawo”, w których wtedy się zaczytywałam”. W pismach tych przeczytała, że rzeczą całkowicie naturalną jest sytuacja, gdy 15-letnia dziewczyna ma chłopaka, z którym współżyje. Jola pomyślała wtedy, że też tak zrobi, aby nie być ,inna”. To był początek. Teraz ma 17 lat. „Puszczać się za pieniądze zaczęłam rok temu, gdy mój chłopak «Gigant» zginął «po pijaku» w wypadku samochodowym"19. W najbliższym czasie nie zamierza zmienić swego życia. Nie widzi w nim niczego nagannego, podobnie jak inni badani. Prostytucja jest dla nich wygodnym sposobem zaspakajania rozbudzonych potrzeb konsumpcyjnych.

Historia opowiedziana przez siedemnastoletnią Jolę dobitnie ukazuje, jak ważną rolę w poznaniu rzeczywistości spełniają kontakty z mediami, jak bardzo wyznawane przez współczesnego człowieka poglądy i opinie zależą od tego, co pokazuje telewizja, o czym się pisze w Internecie, co można przeczytać w gazetach. Na podstawie zachowań bohaterów medialnych tworzone są wyobrażenia o tym, co dobre i właściwe, a co niewłaściwe i złe. Treści, które przedstawiają media, nie tylko odtwarzają istniejącą rzeczywistość, ale także ją konstruują kształtują wyobrażenia o trendach i kierunkach zachodzących w świecie zmian, o najistotniejszych cechach porządku społecznego. Media są podstawowym obszarem konstruowania rzeczywistości społecznej, polem, na którym toczy się „walka o znaczenia”, o kierunki i tempo zachodzących zmian społecznych.

\section{Media a socjalizacja i wychowanie}

Warto zwrócić uwagę na jeszcze jedną właściwość mediów. Przekazują one zestaw wiadomości, które są potrzebne do zrozumienia świata. A. E. Be-

17 D. McQuail, dz. cyt., s. 483.

18 J. Kurzępa, Młodzież pogranicza - „świnki”, czyli o prostytucji nieletnich, Kraków 2001.

19 Tamże, s. 148. 
all porównuje te wiadomości do „soczewek”20, przez które obserwujemy świat i dzięki którym ten świat rozumiemy. Sposób postrzegania świata jest uwarunkowany tym, przez jakie „soczewki” na niego patrzymy. Celem socjalizacji jest sprawienie, by dzieci patrzyły na świat przez takie „soczewki”, jakich używają inni członkowie społeczeństwa. Dzięki używaniu tych samych „soczewek" ludzie w podobny sposób rozumieją świat, podobnie zachowują się w określonych sytuacjach, podobnie interpretują informacje. W przeszłości, gdy wiedzę o świecie młody człowiek uzyskiwał przede wszystkim w domu rodzinnym, jego ,soczewki” były pod wieloma względami podobne do „soczewek” rodziców, wiedza o rzeczywistości społecznej z wszystkimi tego konsekwencjami - przekazywana była z pokolenia na pokolenie, w pewnym sensie dziedziczona. Istniała pewna ciagłość wiedzy o życiu, postaw wobec życia, wartości. Dziś najważniejszym i najbardziej autorytatywnym źródłem wiedzy o rzeczywistości społecznej są media, to one stanowią „soczewkę" służącą oglądaniu świata - jednakową dla młodych ludzi z różnych regionów i różnych środowisk. Przez taką właśnie soczewkę dokonuje się dziś socjalizacja. Konsekwencją tego stanu rzeczy jest odrzucenie przez młodych ludzi wiedzy o świecie, jaką dysponowali rodzice (inne „soczewki”), a także unifikacja wyobrażeń o świecie kształtowanych przez „soczewkę mass mediów”.

Analizując udział mediów w procesach socjalizacyjnych, badacze najczęściej skupiają uwagę na telewizji, która do niedawna była medium dominującym i wywierała największy wpływ na zachowanie i obyczaje młodych ludzi. Dziś medium to zaczyna być wspomagane, a nawet wypierane, przez Internet. Korzystanie z Internetu stało się nieodłączną częścią codziennego życia współczesnych dzieci: średnio w Europie 93\% młodych internautów korzysta z Sieci przynajmniej raz w tygodniu, a 60\% loguje się codziennie lub prawie każdego dnia; w Polsce 74\% korzysta z Internetu codziennie, a 24\% 1-2 razy w tygodniu. Ponad połowa badanych młodych Polaków ma własny komputer osobisty, a 13\% korzysta z Internetu we własnym laptopie. 20\% nastolatków w wieku 11-16 lat wykazuje objawy ,problemowego korzystania z Internetu", polegające na tym, że dziecko nie je lub nie śpi, bo woli być w Sieci. Dzieci korzystając z Internetu mogą napotkać zagrożenia w czterech sferach funkcjonowania społecznego: relacjach międzyludzkich opartych na przemocy, agresji i okrucieństwie; wypaczonych kontaktach erotycznych; ustalaniu hierarchii wartości i indoktrynacji w tym zakresie oraz

20 A. E. Beall, Społeczno-konstruktywistyczne podejście do rodzaju, w: B. Wojciszke (red.), Kobiety i mężczyźni: odmienne spojrzenie na różnice, Gdańsk 2002, s. 83. 
działaniach rynkowych. Młodzi użytkownicy Internetu mogą być narażeni na te zagrożenia poprzez zetknięcie się ze szkodliwymi treściami zamieszczonymi w Sieci ${ }^{21}$. Zagrożenia te można w pewnym stopniu minimalizować poprzez zmianę charakteru rodzinnych kontaktów z mediami. Tymczasem od wielu lat badacze mediów zwracają uwagę, że we współczesnych rodzinach dzieci same korzystają z mediów: samodzielnie dokonują selekcji oglądanych $w$ telewizji programów, nie rozmawiają z dorosłymi o ich wartości czy zagrożeniach, jakie one niosą, dorośli rzadko współuczestniczą w oglądaniu programów przeznaczonych dla młodych widzów ${ }^{22}$. Wraz z upowszechnieniem Internetu sytuacja nie polepszyła się. Co prawda większość badanych polskich dzieci $(90,5 \%)$ korzysta $\mathrm{z}$ Internetu w domu, ale ponad $60 \%$ czyni to wyłącznie we własnym pokoju. Wyniki te pozwalają przypuszczać, że wgląd osób dorosłych w to, jak dzieci korzystają z Internetu, jest niewielki, a przez to możliwość minimalizacji zagrożeń, jakie niesie Internet, mocno ograniczona.

Ważny aspekt socjalizacyjnego oddziaływania mediów wiąże się z omówionymi wcześniej zagrożeniami, jakie te oddziaływania niosą. Przez wiele lat media oskarżane były o przyczynianie się do upadku moralności, o nasilanie agresji i patologii społecznej, o demoralizację. Dziś także funkcjonowanie mediów stanowi wygodne psychologiczne rozwiązanie między innymi dla pedagogów szukających przyczyn niewydolności systemu wychowawczego. Media są „kozłem ofiarnym”, zrzuca się na nie odpowiedzialność za całe zło i wszelkie problemy trapiące społeczeństwo. „Łatwiej i bezpieczniej z psychologicznego punktu widzenia jest obwiniać telewizję i inne mass media - wyznaczając im rolę chłopca do bicia, zyskuje się świetne wytłumaczenie dla niepowodzeń nauczycieli i kryzysu nienadążającej za rzeczywistością szkoły, spadku partycypacji politycznej, gwałtownie rosnącej przestępczości czy pustoszejących ław kościołów”23.

Mimo słuszności tych spostrzeżeń nie sposób nie przyznać racji J. Gajdzie, który zwraca uwagę na negatywne aspekty oddziaływań medialnych pisząc, że media:

- prezentują rzeczywistość w krzywym zwierciadle i kreują fałszywą rzeczywistość, eksponują zjawiska patologiczne, przy jednocze-

${ }^{21}$ Wyniki badań „Polskie dzieci w Internecie” dostępne pod adresem: test.swps.pl [dostęp: 25.06.2014].

${ }^{22}$ M. Filipiak, dz. cyt., s. 132-133.

${ }^{23}$ J. Hawrylik, Chłopiec do bicia - krytyka mass mediów w świetle koncepcji Johna B. Thompsona, „Kultura i Społeczeństwo” 3 (1999), s. 115. 
snym braku gruntownej analizy rzeczywistości społeczno-politycznej i przekonujących przykładów zapobiegania zjawiskom negatywnym;

- upowszechniają i utrwalają konsumpcyjny styl życia w wyniku prymatu wartości materialnych; zawężają pojęcia sukcesu głównie do sfery zamożności, rozrywki; unikają treści mówiących o heroicznej pracy, codziennym znojnym trudzie;

- pogłębiają proces dekulturyzacji, obniżają poziom artystyczny przez zalew bylejakości, schlebianie pospolitym gustom, produkcję niewybrednej, ale zyskownej rozrywki ${ }^{24}$.

\section{Zakończenie}

Środki masowego przekazu dostarczają informacji, kreują wizję świata, rozbudzają emocje i potrzeby, kształtują postawy, wpływają na zachowania. Młodzi ludzie dowiadują się z mediów, jak należy się zachowywać, do czego dążyć, czego unikać, co jest atrakcyjne, a co może człowieka ośmieszyć. Media odgrywają więc ważną rolę w konstruowaniu wiedzy społecznej młodych ludzi. Owa wiedza społeczna określa tożsamość młodzieży, charakter jej wyborów (dokonywanych w takim świecie, jakim młodzież go postrzega), jej dylematy, problemy, dążenia.

Scharakteryzowane powyżej negatywne aspekty oddziaływania mediów pozwalają uznać, że mediatyzacja rzeczywistości społecznej stanowi poważne wyzwanie dla procesu socjalizacji. Pedagodzy, wychowawcy i rodzice muszą zastanowić się, jak wobec tej nowej sytuacji postępować. Przecież media same w sobie nie są złe, ,złe są jedynie te, których zawartość nie poddaje się kontroli subsystemu normatywnego"25. Oczywiście nie ma mowy o kontroli w sytuacji, gdy dzieci pozostawione są same sobie w kontaktach z mediami, dlatego uznaję samotność młodych ludzi w kontaktach z mediami za najpoważniejsze zagrożenie współczesnej socjalizacji odbywającej się w zmediatyzowanej rzeczywistości.

24 J. Gajda, Kultura globalna podstawa wspótczesnej paidei, „Pedagogika Kultury” 1 (2005), s. 50-51.

${ }^{25}$ W. Jakubowski, Media, tożsamość i edukacja, w: W. Jakubowski, S. Jaskulska (red.), Kultura mediów, ciało i tożsamość - konteksty socjalizacyjne i edukacyjne, Kraków 2011, s. 20 . 


\section{Mediatization of Contemporaneity and the Processes of Socialization and Upbringing (Summary)}

The aim of this article is the analysis of processes of socialization and upbringing which take place in the contemporary, pre-figurative culture (dominated by the mass media). The main question of this article is: what are the threats to the process of socialization caused by mediatization of social contemporaneity?

Keywords: transformation of culture, socialization, upbringing, mass media, mediatization of contemporaneity

\section{Mediatyzacja współczesności a procesy socjalizacji i wychowania (Streszczenie)}

Celem artykułu jest analiza procesów socjalizacji i wychowania przebiegających we współczesnej kulturze prefiguratywnej, w świecie zdominowanym przez środki masowego przekazu. Podstawowe pytanie, na które starałam się odpowiedzieć, brzmi: jakie zagrożenia dla procesu socjalizacji niesie mediatyzacja rzeczywistości społecznej?

Słowa kluczowe: przemiany kultury, socjalizacja, wychowanie, masowe media, mediatyzacja współczesności 